\title{
脂質膜とペプチドとの相互作用に関する分子論的考察
}

\author{
松 崎 勝 巳 \\ 京都大学薬学部 齿606-01 京都市左京区吉田下阿達町
}

\section{Molecular-level Considerations on Lipid Membrane-peptide Interactions}

\author{
Katsumi Matsuzaki \\ Faculty of Pharmaceutical Sciences, Kyoto \\ University, Sakyo-ku, Kyoto 606-01, JAPAN
}

\begin{abstract}
We have investigated the interactions of three classes of antimicrobial peptides (hypelcin $\AA$, trichopolyn I, and magainins) with lipid bilayers by using several physichochemical techniques (fluorescence, circular dichroism, infrared absorption, and differential scanning calorimetry) to obtain basic information on the molecular-level mechanisms for their bioactivities. In zwitterionic phosphatidylcholine membranes, hydrophobic peptides, hypelcin A and trichopolyn I, form helices, deeply penetrating the hydrophobic region of the bilayers. There are no specific interactions between membranebound peptide molecules. The penetration disrupts the lipid packing, permeabilizing the bilayers. The membrane action of hypelcin A, the larger peptide, is three fold stronger. In contrast to these hydrophobic peptides, cationic magainin peptides specifically bind with acidic lipid bilayers, e.g., phosphatidylglycerol, to form amphiphilic helices. Electrostatic interactions are important in the binding process. The helical rods lie parallel to the membrane surface and form an aggregate. Magainins cause minimal perturbation of the hydrophobic core of the membranes, coinciding with much weaker membrane permeabilization activity. However, detailed permeabilization mechanisms are a subject of further study.
\end{abstract}

Key words : peptide-lipid interaction, hypelcin A, trichopolyn I, magainins, membrane permeability

\section{1.はじめに}

ペプチドと脂質膜との相互作用は, 様々な観点から研 究がなされており ${ }^{1,2)}$, 大きく次のように分類できる.

(1) 生理活性ペプチドの作用機序の解明（抗菌性ペプ チドやホルモンなよ゙)

(2) タンパク質一脂質分子集合体の構築原理の探求 （生体膜, 血漿リポタンパク質なよ゙）

(3) ペプチド 膜相互作用の関与する生物学的プロセ
スの分子論的理解（生合成されたタンパク質のターゲッ ティング, ウイルス感染なよ゙)

我々はこれまで, 菌細胞膜の透過性充進が作用機構で あると考えられる数種の抗菌性ペプチド (hypelcin A， trichopolyn I, magainins, tachyplesin I) について 上記 (1) の観点から, 生体膜の基本構造をなす脂質膜と の相互作用を分光学的・熱的測定法を用いて研究してき

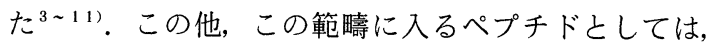
alamethicin, melittin, cecropins, defensins, gram- 


\section{Hypelcin A-I}

Ac-Aib-Pro-Aib-Ala-Aib ${ }^{5}$-Aib-Glø-Aib-Leu-Aib ${ }^{10}$-Gly-Aib-Aib-Pro-Val ${ }^{15}$-Aib-Aib-Gl@-Gln-leucinol ${ }^{20}$

\section{Trichopolyn I}

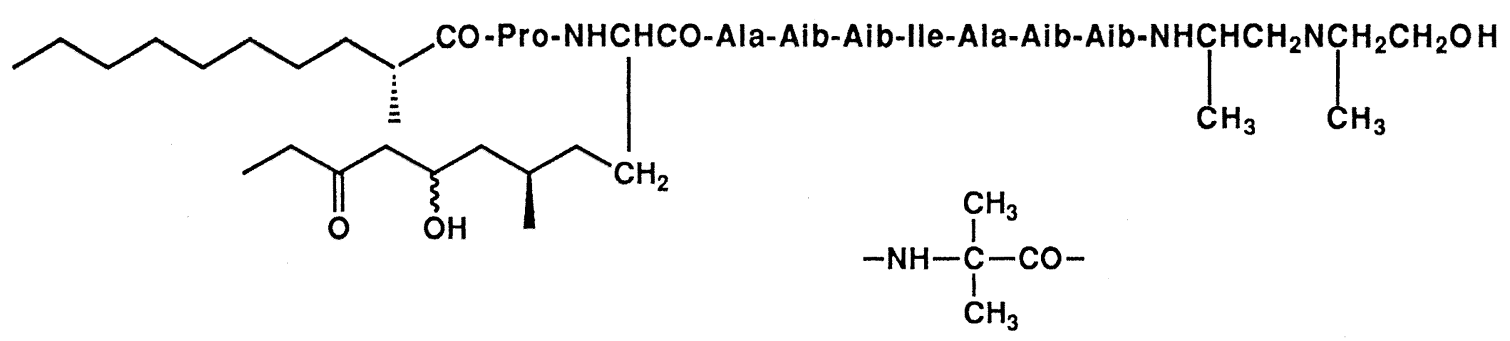

\section{Aib: $\alpha$-aminoisobutyric acid}

図 1. hypelcin A (上) と trichopolyn I (下) の構造.

hypelcin A は構造のよく似た数種の混合物からなるので，主要な A - I についてのみ示した，親水性アミノ酸 はアウトラインで示してある.

icidin, gramicidin S などがあり, いずれもアミノ酸 十数個〜三十数個からなる比較的小さなペプチドであ る.これらぺプチドによる膜の透過性六進の機構として は, チャンネル形成・膜構造の損傷・可溶化等が考えら れる. 分子論的に作用機構を明らかにするには，ペプチ ドの膜中でのコンホメーション・配向・会合状態, ペプ チドによる脂質分子のコンホメーション变化・配向変化 や膜透過性変化, さらには膜の形態変化を詳細に検討し なければならない，ここでは，電荷を持たない疎水性ぺ プチドである hypelcin A と trichopolyn I および正電 荷を持つ両親媒性ペプチドである magainins について 著者らが行った研究結果について述べることにする，特

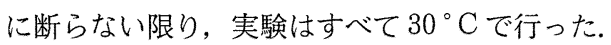

\section{Hypelcin A および trichopolyn $\mathrm{I}^{3 \sim 5)}$}

これらは不完全菌類から得られるペプチドであり, 異 常アミノ酸である $\alpha$ aminoisobutyric acid (Aib) を 高率で含んでいて疎水性が高い(図 1)12〜16). グラム 陽性菌や真菌に対して抗菌性を示す，まず，膜透過性穴 進作用を検討するため, 卵黄 phosphatidylcholine リ ポソームに内包した蛍光色素カルセインの漏出を調 べた ${ }^{3.5)}$. 内包した高濃度 $(70 \mathrm{mM})$ のカルセインは二 量体を形成し自己消光をしているが，漏出すると著しい
希釈を受けるため単量体となり，蛍光を発するようにな ることを利用して膜のバリア一能を評価することができ る.ここで, 透過性上昇が起こるステップを考えてみる. まず，ペプチドが膜に結合する．このときの結合の仕方 すなわち結合等温線はぺプチドの膜内での会合性を反映 する ${ }^{17)}$.引き続いて，膜に結合したぺプチドがなんら かのメカニズムで膜構造を乱し，内包物を漏出させる. 我々はこの 2 つのステップを分離して評価した。

漏出速度（ペプチド添加 1 分後の漏出\%で表現）は, ペプチド濃度 $[\mathrm{P}]_{0}$ が高いほど，また脂質濃度 $[\mathrm{L}]$ が低 いほど，大きかった（図 $2 \mathrm{a}$ )。このことは， $[\mathrm{P}]_{0}$ の絶 対值ではなく, 脂質 1 分子当たりの結合ペプチド量 $\mathrm{r}$ が 透過性変化を決定していることを示している，そこで図 2 で，ある一定の漏出速度（例えば点線で示した $40 \%$ $/ 1 \mathrm{~min})$ を示す 4 つの実験条件 $\left([\mathrm{P}]_{0}\right.$ と $[\mathrm{L}]$ の組み合 わせ）は，同じ $\mathrm{r}$ をえる条件としてよい，結合平衡に 達しているので, 対応する $[\mathrm{P}]_{f}$ (フリーのペプチド濃 度）の值も共通となる. material balance の式

$$
[\mathrm{P}]_{0}=[\mathrm{P}]_{f}+\mathrm{r}[\mathrm{L}]
$$

を考慮すると，この 4 つの条件で $[\mathrm{L}]$ に対し $[\mathrm{P}]_{0}$ をプ ロットすると直線となり, 切片と勾配から $[\mathrm{P}]_{f}$ と $\mathrm{r}$ が それぞれ求まることになる（図 $2 \mathrm{~b}$ )。このようにして, 種々の漏出速度について $[\mathrm{P}]_{f}$ と $\mathrm{r}$ との関係（結合等温 線）を求めたのが図 $3 \mathrm{a}$ である. 同時に得られる漏出速 

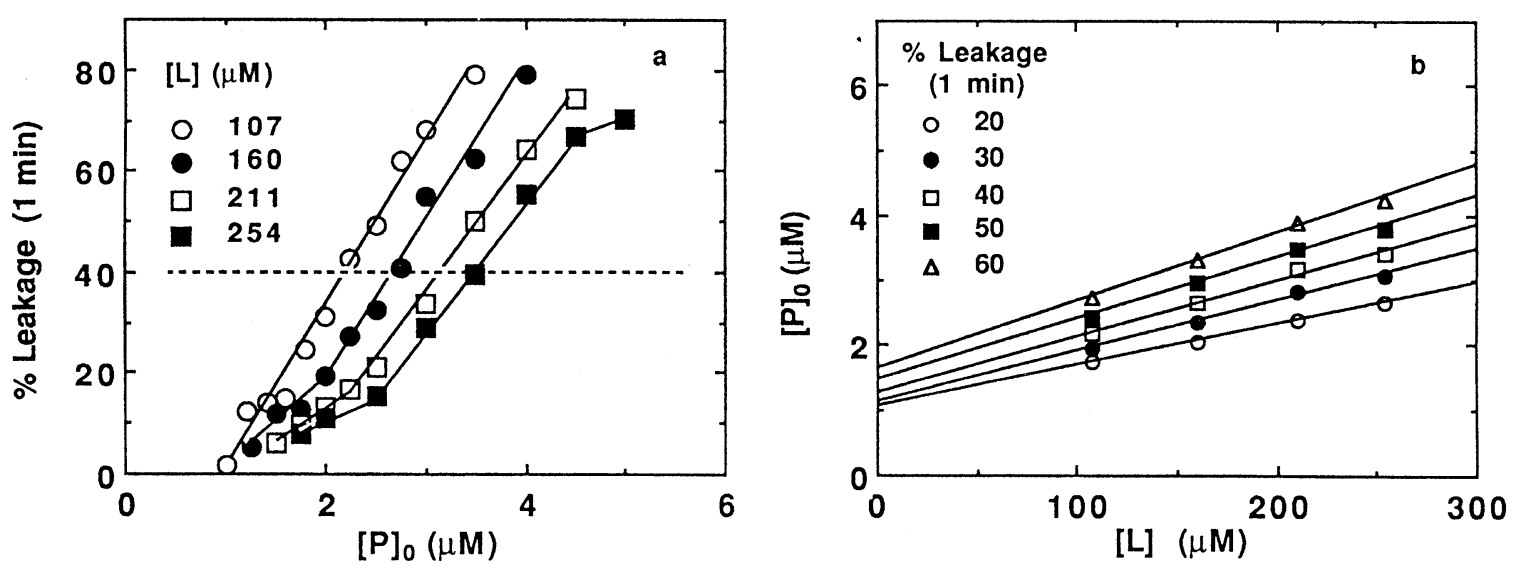

図 2. hypelcin A による卵黄 phosphatidylcholine small unilamellar vesicle の透過性変化 ${ }^{3)}$.

a) 種々の脂質濃度 $[\mathrm{L}]$ におけるペプチド添加 1 分後の内包カルセインの漏出パーセントをペプチド濃度 $[\mathrm{P}]$ に対してプロットした。

b) a) で同じ漏出パーセントを示す 4 点について, $[\mathrm{P}]_{0}$ に対して $[\mathrm{L}]$ をプロットした.
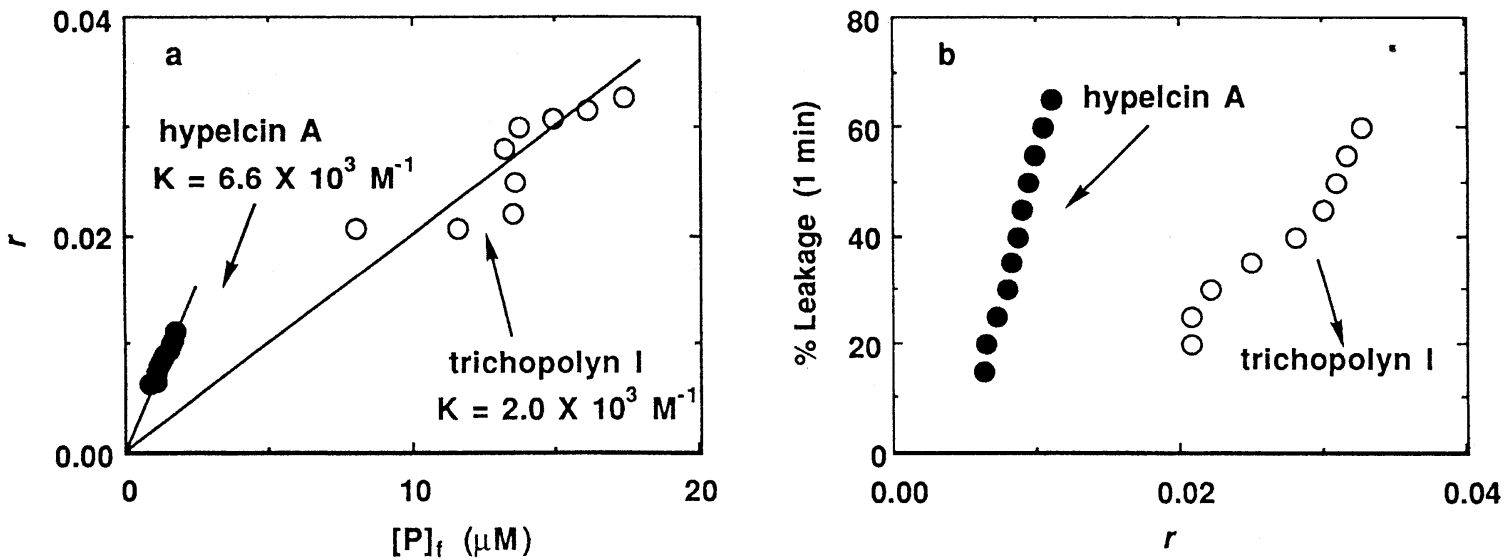

図 3.

a) hypelcin $\mathrm{A}$ と trichopolyn I の卵黄 phosphatidylcholine small unilamellar vesicle への結合等温線.

$[\mathrm{P}]_{f}$ : フリーのペプチド濃度, $\mathrm{r}$ : 脂質 1 分子当りの結合ペプチド量.

b) $\mathrm{r}$ と透過性変化の関係.

度と $\mathrm{r}$ との関係を図 $3 \mathrm{~b}$ に示した。これらのペプチドの 膜への結合は分配平衡(結合等温線が直線)で説明され，

膜中ではぺプチド同士の顕著な会合はないことがわかっ た. 分配係数（直線の傾き）は hypelcin A のほうが約 3 倍大きかった（図 3 a). 膜透過性变化に必要な結合 ペプチド量は hypelcin A のほう（脂質約 100 分子当り ペプチド 1 分子）が約 $1 / 3$ ですむことがわかった（図 3 b).こうした hypelcin A の膜作用の強さは溶血性にも 反映されていた ${ }^{5)}$.また，これらのペプチドはリポソー ムの融合を惹起するが, 透過性変化は融合に伴うもので
はないことを明らかにしだ，5)。

次に, これらペプチドの膜透過性上昇作用の機構を探 るため, 膜のゲル一液晶相転移に及ぼす影響について DSC を用いて検討した ${ }^{3,5)}$ 。これらぺプチドの添加に より dipalmitoylphosphatidylcholine (DPPC) の相 転移は消失した，相転移に伴うエンタルピー変化は主に 脂質の炭化水素鎖の融解に基づくもの之考えられている から，これらのペプチドは膜の疎水部に大きな影響を与 えていると考えられる.

そこで,さらに詳細に分子レベルでの知見を得るため, 


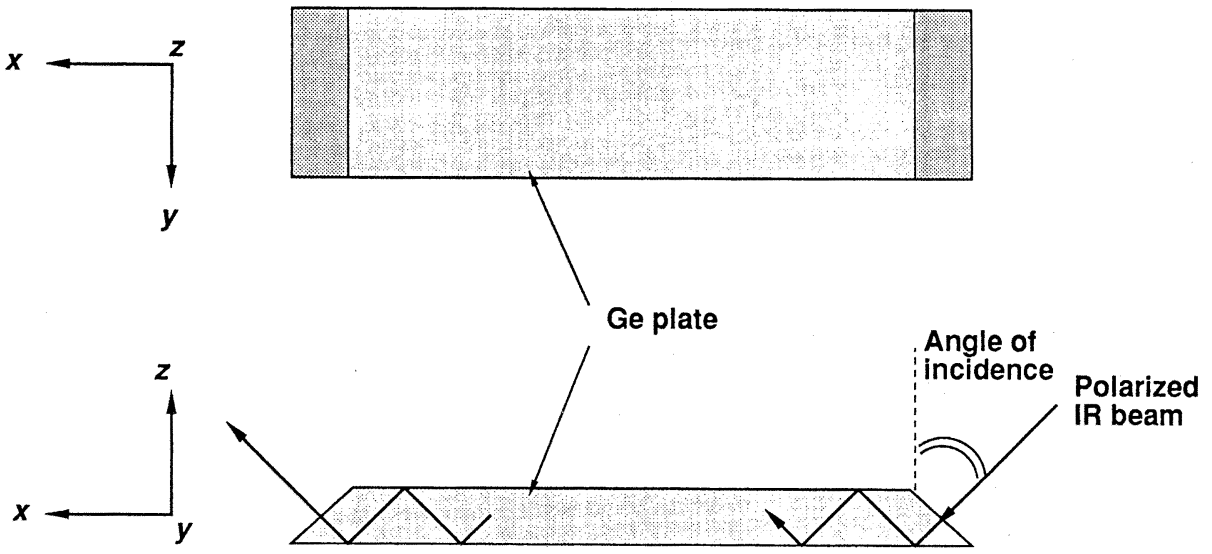

図 4. ATR 法の原理 ${ }^{5)}$.

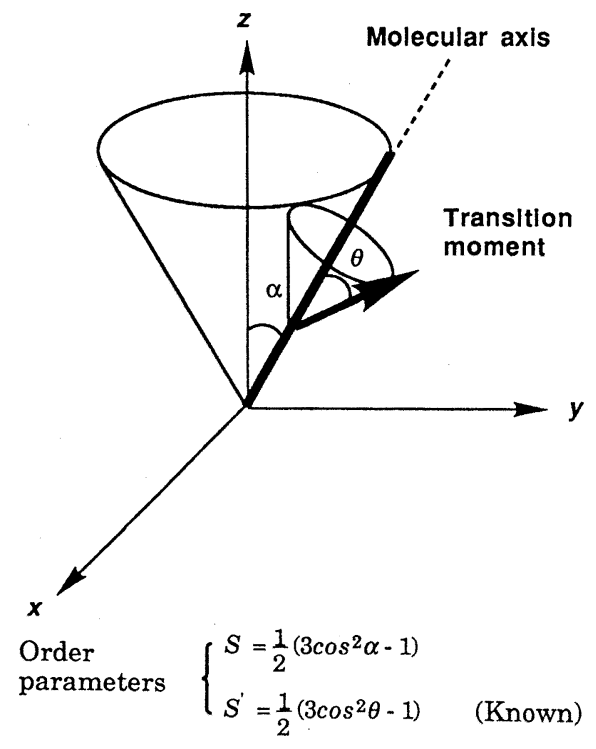

図 5. 一軸配向モデル ${ }^{5)}$.

FTIR 偏光 ATR 測定を行った ${ }^{5)}$. この方法の概略を図 4 に示す. 高屈折率の $\mathrm{Ge}$ 板の上面に DPPC とペプチ ドからなる配向膜を調製する.この板に入射角 45 度で 2 種類の赤外偏光（電場ベクトルが入射面に平行および 垂直) を入射する. 光は $\mathrm{Ge}$ 一膜界面で全反射を繰り返 し, 入射した方向と逆方向に出てゆき検出される.この とき, 赤外光は膜側に $0.2 \sim 0.8 \mu \mathrm{m}$ 滲み出すので, 膜 に関する情報が得られる. 赤外光の吸収強度は光の電場 ベクトルと吸収の遷移モーメントベクトルの内積の二乗 に比例するから, 2 種の偏光に対する吸光度の比から $\mathrm{Ge}$ 板に対する遷移モーメントの配向を知ることができ
る.すなわち, 用いる赤外吸収バンドによってペプチド や脂質分子の配向を評価できる. 我々は, 十分厚い膜 $(6$ $\mu \mathrm{m})$ を重水で水和して用いた.この条件下で, 図 5 に 示した一軸配向を仮定すると, 問題とする遷移モーメン トの配向は (2) 式で求められる.

$$
\mathrm{S} \cdot \mathrm{S}^{\prime}=(\mathrm{R}-2.00) /(\mathrm{R}+1.45)
$$

ここで, $\mathrm{R}$ は二色比と呼ばれ 2 種類の赤外偏光による吸 光度の比 $\left(\Delta \mathrm{A} \| / \Delta \mathrm{A}_{\perp}\right)$ である. $\mathrm{S}, \mathrm{S}^{\prime}$ は $\mathrm{z}$ 軸のまわりの 分子軸の，および分子軸まわりの遷移モーメントのそれ ぞれオーダーパラメーターである.

$$
\begin{aligned}
& \mathrm{S}=\left(3 \cos ^{2} \alpha-1\right) / 2 \\
& \mathrm{~S}^{\prime}=\left(3 \cos ^{2} \theta-1\right) / 2
\end{aligned}
$$

図 6 a は DPPC の炭化水素鎖の C-H の対称伸縮振 動の波数の温度変化である. ペプチドを添加していない 場合, $41^{\circ} \mathrm{C}$ 付近で急激な高波数シフトが見られた. こ れは炭化水素鎖の融解に伴い, オールトランス型から ゴーシュ型が混じったコンホメーションになったことを 示している. DPPCに5 mol\%の hypelcin A を添加 した場合も同様であった. しかし, trichopolyn I を添 加した場合には, 高波数シフトが消失し, 高温でもオー ルトランス型に近いコンホメーションをとっていること がわかった.

図 $6 \mathrm{~b}$ は炭化水素鎖のオーダーパラメーター S の温度 変化である. DPPC のみの場合, ゴーシュ型の増加に 由来するオーダーの低下が $41^{\circ} \mathrm{C}$ 付近で見られた. trichopolyn I を添加した場合には, 全温度領域でオー ダーが低下した．波数変化からはゴーシュ型の増加が観 測されなかったことから, trichopolyn I の添加により 脂質の配向軸自体が $\mathrm{z}$ 軸から傾いたと考えられる. hy- 

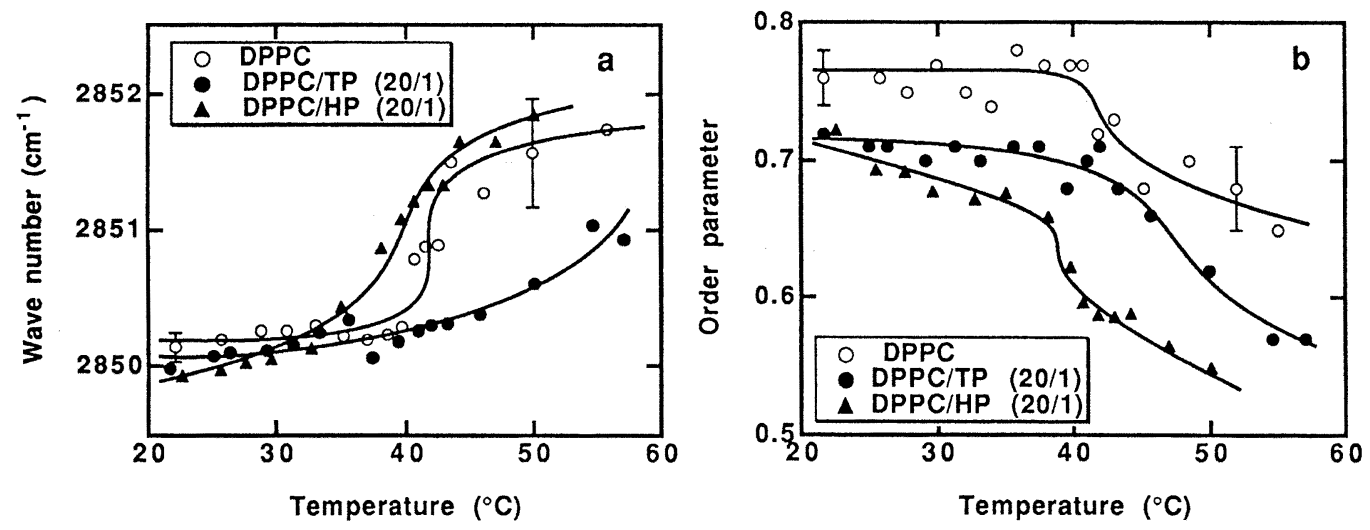

図 6. FTIR 偏光 ATR 法による脂質炭化水素鎖のコンホメーションと配向 ${ }^{5)}$. ペプチド/DPPC $(1 / 20)$ 配向膜を重水で水和して測定. ( Ge plate, $45^{\circ}$ incidence, $\left.\mathrm{D}_{2} \mathrm{O}\right)$

a) $\mathrm{C}-\mathrm{H}$ 対称伸縮振動の波数の温度変化.

b) DPPC 炭化水素鎖のオーダーパラメーターの温度変化. HP : hypelcin A, TP : trichopolyn I.

表 1. FTIR 偏光 ATR 法によるペプチドのコンホメーションと配向

\begin{tabular}{|c|c|c|c|}
\hline Peptide & Temp. $\left({ }^{\circ} \mathrm{C}\right)$ & Frequency $\left(\mathrm{cm}^{-1}\right)$ & Order parameter $(\alpha)$ \\
\hline Hypelcin A & $\begin{array}{l}22 \\
50\end{array}$ & $\begin{array}{l}1658.1 \\
1658.9\end{array}$ & $\begin{array}{rr}-0.05 & \left(57^{\circ}\right) \\
0.08 & \left(52^{\circ}\right)\end{array}$ \\
\hline Trichopolyn I & $\begin{array}{l}22 \\
50\end{array}$ & $\begin{array}{l}1666.7 \\
1666.7\end{array} 3_{10}$-helix & $\begin{array}{ll}-0.09 & \left(58^{\circ}\right) \\
-0.09 & \left(58^{\circ}\right)\end{array}$ \\
\hline
\end{tabular}

*DPPC/Peptide (20/1) film hydrated with $\mathrm{D}_{2} \mathrm{O}$
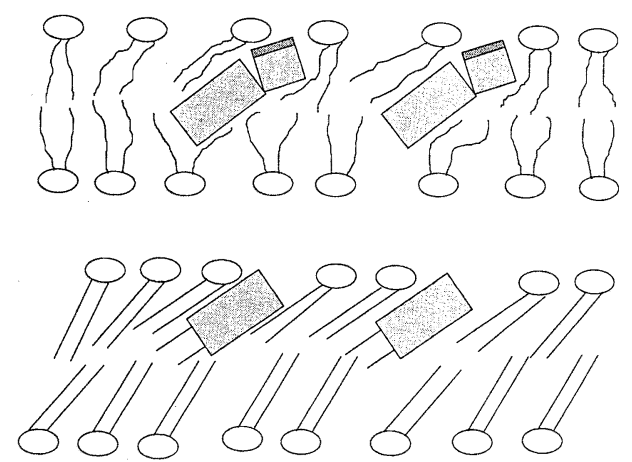

図 7. 脂質膜中での hypelcin A (上) と trichopolyn I (下) の存在状態の模式図 (液晶温度).

pelcin A を添加した場合には，この傾向がさらに顕著 であったが，この事実は上述した膜作用の強さを説明す ることができる.

次に, ペプチドのコンホメーションならびに配向につ いて検討した（表 1).アミドIの波数はペプチドの二
次構造を反映する ${ }^{18)}$. hypelcin A は $1658 \mathrm{~cm}^{-1}$ 付近 で， $\alpha$-ヘリックス構造であることがわかった。一方, trichopolyn I は $1667 \mathrm{~cm}^{-1}$ 付近で, $33_{10}$-ヘリックス構 造であった.これらペプチドがヘリックス構造をとるこ とは, CD スペクトルの結果からも支持された. 一般 に, Aib を含むぺプチドのうち, 10 残基以下の短いもの は $3_{10}$-ヘリックス構造をとり, それより長い物は $\alpha$-へ リックス構造をとることが知られている ${ }^{19)}$ 。これらの ヘリックスの膜内での配向を調べたところ, 表 1 に示し たように $\mathrm{S}$ はほぼ 0 となった。すなおち, ペプチドは ランダムに配向しているか, あるいは, 偶然マジックア ングル（54.7 度）近傍の角度をもって配向している. いずれにしても，ヘリックスは膜の疎水部深くに侵入し ているが, 膜面に平行あるいは垂直といったきちんとし た入りかたをしていない，このため周りの脂質の配向を 乱すものと考えられる.

以上の結果を模式的に示したのが図 7 である（液晶状 態). hypelcin A のヘリックスが折れ曲がっているの 


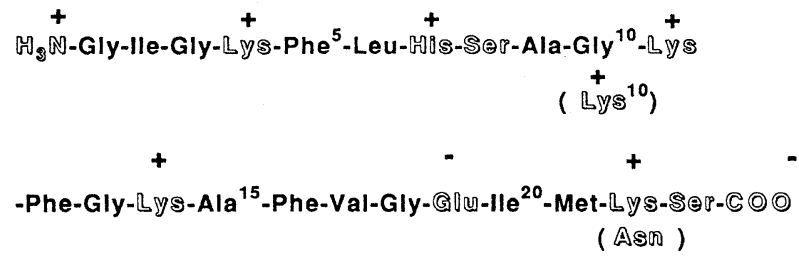

(Asn)

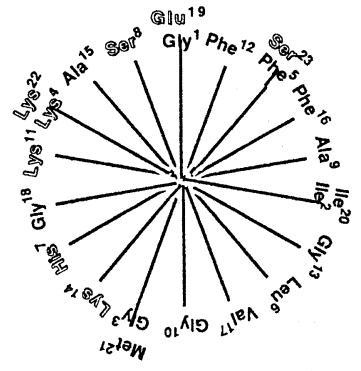

Helical wheel of magainin 1

"Amphiphilic helix"

図 8. magainins のアミノ酸配列(左)とヘリックス車輪(右).

magainin 2 は magainin 1 と（）内の 2 残基が異なる. 親水性アミノ酸はアウトラインで示し てある。

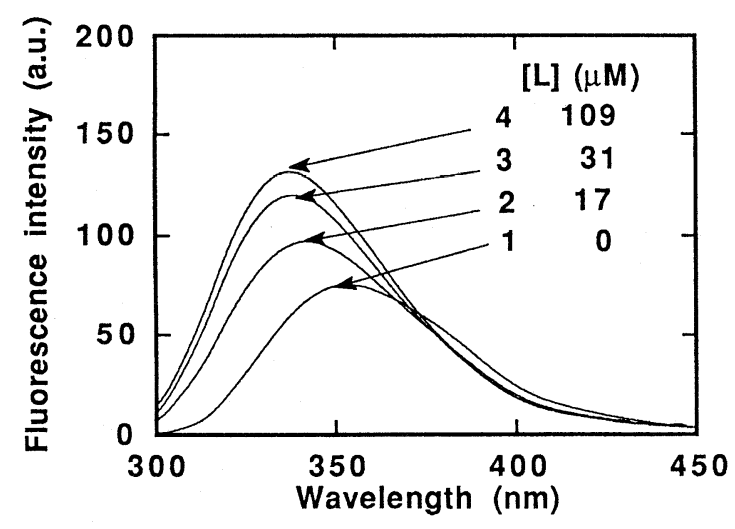

図 9. $5 \mathrm{~W}$ - magainin 2 の蛍光スペクトル9). 励起 $280 \mathrm{~nm}$. [P $]_{0}$ は $5 \mu \mathrm{M}$. [L] は卵黄 phosphatidylglcerol (large unilamellar vesicle) 濃 度.

は, 14 番目のProによる. また， C 末端領域にある Gln, Phol のプロトン供与基は脂質のリン酸基と水素 結合しているらしいことが, IR のデータから示唆され た ${ }^{5)}$.

\section{Magainins ${ }^{6 \sim 9)}$}

Magainins は 1987 年 NIH の Zasloff によってアフ リカツメガエルの皮膚より単離された抗菌性ペプチド で,この動物の host-defense system に関与している と考えられている ${ }^{20)}$. 本ペプチドの抗菌スペクトルは 広く, グラム陽性・陰性菌, 真菌類に有効である. アミ ノ酸配列(図 8)を見ると, 荷電アミノ酸（主に塩基性,
アウトラインで示してある）が周期的に繰り返され，そ れらの間に2〜4 個の疎水性アミノ酸が挟まれているこ とから，両親媒性へリックスを形成することが予想され る(図 8 右, ヘリックス車輪)。事実, 我々は, magainin 1 がマイナス荷電をもつ酸性リン脂質膜とのみ相 互作用し, 両親媒性へリックスを形成し, 膜透過性を上 げることを見いだした ${ }^{6)}$. 両親媒性へリックスを形成す るには, プラス荷電が近接して存在しなければならず, 反発が生じる. 膜面のマイナス荷電がこれを中和する必 要があると思われる. magainin の膜への結合性におけ る静電的相互作用の重要性は, 媒質の塩濃度の減少によ り結合性が低下することによって裏付けられた7)。 た, 細菌の細胞膜との相互作用に関しても, 酸性リン脂 質との相互作用が重要であることを見いだした ${ }^{8)}$.

膜との相互作用をさらに詳細に検討するため, magainin 2 の $5,12,16$ 番目の Phe をそれぞれ Trp に 1 残 基置換した誘導体を合成し，菌細胞膜に豊富に存在する 酸性リン脂質である phosphatidylglycerol (卵黄由 来）からなる膜との相互作用を調べた ${ }^{9)}$. これらの誘導 体は膜中でのコンホメーションや膜透過性六進において 親ペプチドと同等であることを確認した．膜に結合する と Trpの蛍光はブルーシフトし強度が増大し, Trp が 膜の疎水部に存在することがわかった（図 9).この蛍 光変化を指標にして結合等温線を求めることにした. 解 析にはしばしば二状態モデルが用いられるが，ここでは より一般的な方法を適用した. 膜が存在しない時, Trp の蛍光強度は次式で与えられる.

$$
\mathrm{F}_{0}=\mathrm{k}_{f}[\mathrm{P}]_{0}
$$




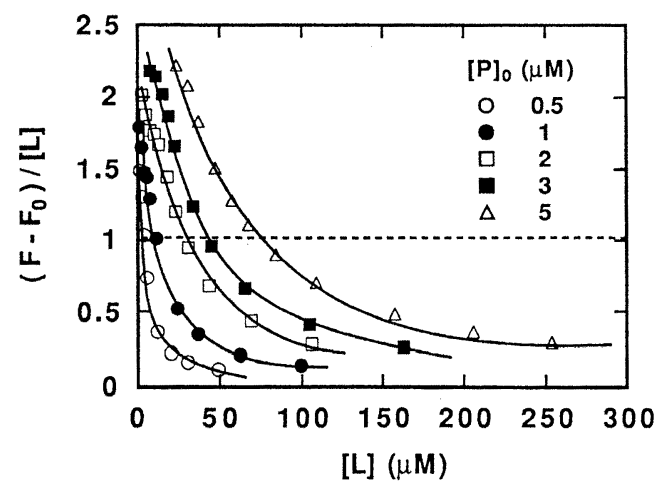

図 10. 種々のペプチド濃度における, 脂質添加に 伴う $5 \mathrm{~W}$-magainin 2 の蛍光強度 F (336 $\mathrm{nm}$ ) の変化 ${ }^{9)}$.

$\mathrm{F}_{0}$ は脂質なしのときの $\mathrm{F}$.

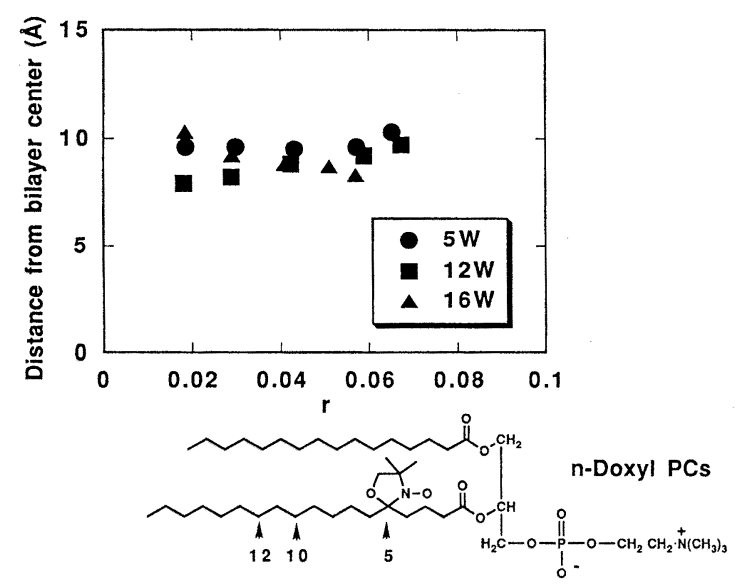

図 12. 視差法により見積った各 $\operatorname{Trp}$ 残基の膜中心 からの距離と $\mathrm{r}$ との関係.

n-doxylphosphatidylcholine の構造もあ わせて示した.

一方, 膜存在下では,

$$
\mathrm{F}=\mathrm{k}_{f}[\mathrm{P}]_{f}+\mathrm{k}_{b} \mathrm{r}[\mathrm{L}]
$$

ここで, $\mathrm{k}$ はペプチドの蛍光係数（量子収率）であり, 添え字 $\mathrm{f}, \mathrm{b}$ はそれぞれフリーおよび結合型を表す. $\mathrm{k}_{f}$ は定数であるが, $\mathrm{k}_{b}$ は結合量 $\mathrm{r}$ に依存する可能性があ る. (5) (6) 式から, (7) 式が得られる.

$$
\left(\mathrm{F}-\mathrm{F}_{0}\right) /[\mathrm{L}]=\left(\mathrm{k}_{b}-\mathrm{k}_{f}\right) \mathrm{r}
$$

右辺は $\mathrm{r}$ のみに依存する関数であるから, 図 10 で縦軸 の価が同じ点(例えば破線で示した 1 の点) は, 同じ $r$, したがって同じ $[\mathrm{P}]_{f}$ を持つことになる. 図 2 から図 3 を求めたのと同じ方法で結合等温線を求めたところシグ

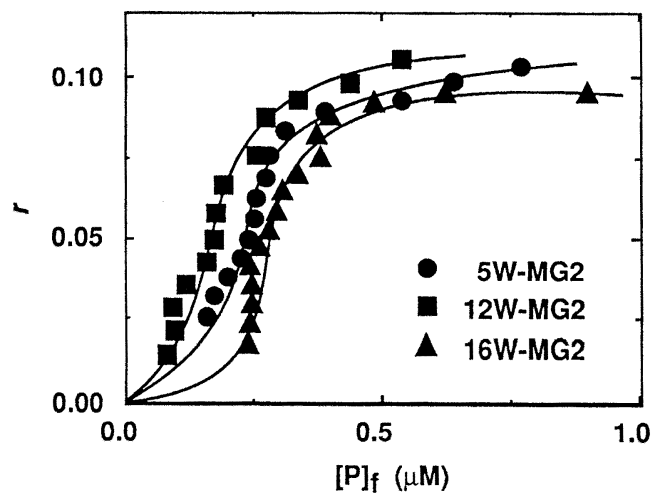

図 11. 3 種の $\operatorname{Trp}$ 置換 magainin 2 の卵黄 phosphatidylglycerol (large unilamellar vesicle) への結合等温線 ${ }^{9}$.

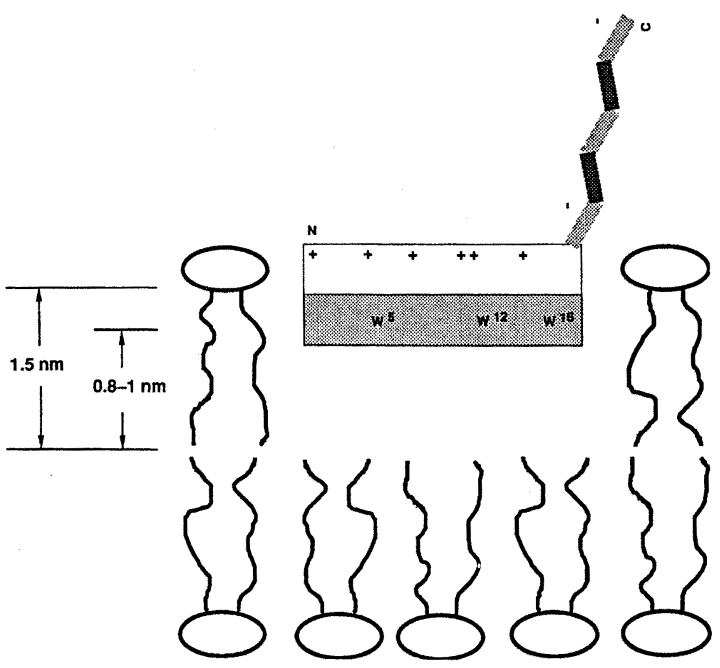

図 13. 脂質膜中での magainin ヘリックスの配向 の模式図.

モイド型(正の協同性)となった（図 11). 正電荷を持っ たペプチドの結合により, 膜のマイナス荷電は減少する ので，ペプチド一膜間の静電引力は徐々に減少するはず である．にもかかわらずこのような正の協同性を示すと いうことは，ペプチド同士が膜内で会合している可能性 を示唆するものである.

$\operatorname{Trp}$ 残基の膜中での深さを推定するため $n$-doxylphosphatidylcholines $(n=5,10,12$, 図 12 下) を用 いて蛍光消光実験（視差法 ${ }^{21)}$ ) を行ったところ, い ずれの Trp 残基も膜の疎水部の中心から $\mathrm{r}$ によず $0.8 \sim 1 \mathrm{~nm}$ の距離にあり（図 12）, magaininヘリッ クスは膜表面付近に横たわっていることが明らかと 
なった（図 13）。これはヘリックスの両親媒性から見て 妥当なものである.このような配向でのペプチド同士の 会合としては，逆平行へリックスを基本構造としたもの である可能性が考えられるが, 詳細はいまのところ明ら かでない.

膜透過性変化はペプチドによる膜構造の乱れである可 能性があるが，その力はかなり弱い。なぜなら, magainin は dipalmitoylphosphatidylglycerol の相転移 に殆ど影響しないし，また，膜透過性変化に必要な結合 ペプチド量はほぼ同じ分子サイズの hypelcin A に比べ ておよそ 10 倍必要であるからである7 ${ }^{7}$. しかし, 大部 分のペプチドは膜面に平行であるが，ごく一部のペプチ ドが膜を貫通して pore を形成している可能性もある. 詳細な膜透過性六進のメカニズムは今後の検討課題であ る.

\section{4. おわりに}

以上, 筆者の行った研究のうち, 3 種の膜作用性の抗 菌性ペプチドについての結果を述べた。このような membrane-lytic ペプチドについては, polymyxins, alamethicin, melittin などに関して膨大な研究がこの 20 年間になされている1, 2) が, ペプチドが膜によ゙のよ うな侵入の仕方をし, その結果, なせ⿺透過性亢進が起こ るのかという本質的なことに関しては依然, 議論の分か れるところである. また, 生体膜では膜電位が存在する が, これがペプチドと脂質膜との相互作用にどのような 影響を及ぼしているかは, 生物物理化学的にきわめて重 要な問題であるにもかかわらず，ほ上んど何も解かって いないのが現状であり, 今後の研究の進展を待たねばな らない。

最後に, 本シンポジウムでの発表の機会を与えてくだ さいました委員の諸先生に深謝致します。また，本研究 は京都大学薬学部 藤多哲朗教授, 藤井信孝教授, およ び京都大学化学研究所 竹中亨教授の各研究室との共同 研究によるものであり, ここに感謝致します.

\section{参考文献}

1) M. S. P. Sansom, Prog. Biophys. Molec. Biol. 55. 139 (1991).

2) E. T. Kaiser F. J. Kézdy, Ann. Rev. Biophys.
Biophys. Chem. 16, 561 (1987).

3) K. Matsuzaki, S. Nakai, T.Handa, Y. Takaishi, T. Fujita and K. Miyajima, Biochemistry 28, 9392 (1989).

4) K. Matsuzaki, Y. Takaishi, T. Fujita and K. Miyajima, Colloid Polym. Sci. 269, 604 (1991).

5) K. Matsuzaki, T. Shioyama, E. Okamura, J. Umemura, T. Takenaka, Y.Takaishi, T. Fujita and K. Miyajima, Biochim. Biophys. Acta 1070, 419 (1991).

6) K. Matsuzaki, M. Harada, T. Handa, S. Funakoshi, N. Fujii, H. Yajima and K. Miyajima, Biochim. Biophys. Acta 981, 130 (1989).

7) K. Matsuzaki, M. Harada, S. Funakoshi, N. Fujii and K. Miyajima, Biochim. Biophys. Acta 1063, 162 (1991).

8) K. Matsuzaki, M. Harada, S. Funakoshi, N. Fujii and K. Miyajima: "Peptide Chemistry 1990" (Y. Simonishi, ed.) p. 389, Protein Research Foundation, Osaka, (1991)

9) K.Matsuzaki, O. Murase, H. Tokuda, S. Funakoshi, N. Fujii and K. Miyajima : "Peptide Chemistry 1991” (A. Suzuki, ed.) p.269, Protein Research Foundation, Osaka, (1992).

10)K. Matsuzaki, M.Fukui, N. Fujii and K. Miyajima, Biochim. Biophys. Acta 1070, 259 (1991).

11) K.Matsuzaki, M. Fukui, N. Fujii and K. Miyajima, Membrane Symposium 3, 76 (1991).

12) K. Fuji, E. Fujita, Y. Takaishi, T. Fujita, I. Arita, M. Komatsu and N. Hiratsuka, Experientia 34, 237 (1978).

13) T. Fujita, Y. Takaishi and T. Shiromoto, J. Chem. Soc. Chem. Commun. 413 (1979).

14) T. Fujita, Y. Takaishi and A. Okamura, J. Chem. Soc., Chem. Commun. 585 (1981).

15) T.Fujita, Y.Takaishi, K.Matsuura, Y.Takeda, Y. Yoshioka and H. Brückner, Chem. Pharm. Bull. 32, 2870 (1984).

16) T. Fujita, Y. Takaishi, H. Moritoki, T. Ogawa and K. Tokimoto, Chem. Pharm. Bull. 32, 1822 (1984).

17) G. Schwarz, Biochimie 71, 1 (1989).

18) D. M. Byler and H. Susi, Biopolymers 25, 469 (1986).

19) D. F. Kennedy, M. Crisma, C. Toniolo and D. Chapman, Biochemistry 30, 6541 (1991).

20) M. Zasloff, Proc. Natl. Acad. Sci. USA 84, 5449 (1987).

21) A. Chattopadhyay and E. London, Biochemistry 26, 39 (1987).

（受付 1992 年 8 月 24 日） 